\title{
An Unusual Mechanism of Glycoside Hydrolysis Involving Redox and Elimination Steps by a Family $4 \beta$-Glycosidase from Thermotoga maritima
}

\author{
Vivian L.Y. Yip ${ }^{a}$, Annabelle Varrot ${ }^{b}$, Gideon J. Davies ${ }^{b}$, Shyamala S. Rajan ${ }^{c}$, Xiaojing \\ Yang $^{\mathrm{c}}$, John Thompson ${ }^{\mathrm{d}}$, Wayne F. Anderson ${ }^{\mathrm{c}}$, and Stephen G. Withers ${ }^{\mathrm{a},{ }^{*}}$ \\ ${ }^{a}$ Department of Chemistry, University of British Columbia, Vancouver, BC, Canada, V6T 1Z1 \\ ${ }^{b}$ Structural Biology Laboratory, Department of Chemistry, University of York, Heslington, York \\ Y010 5YW, U.K. \\ ${ }^{c}$ Molecular Pharmacology and Biological Chemistry, Feinberg School of Medicine, Northwestern \\ University, Chicago, Illinois 60611, USA. \\ ${ }^{d}$ Microbial Biochemistry and Genetics Unit, Oral Infection and Immunity Branch, NIDCR, National \\ Institutes of Health, Bethesda, Maryland 20892, USA.
}

\section{Supporting Information}

\section{Experimental Methods}

\begin{abstract}
Materials.
${ }^{1}$ H NMR spectroscopy was performed on Bruker Avance 300, Bruker Avance 400, and Bruker AMX-500 spectrometers at 300, 400, and $500 \mathrm{MHz}$ respectively. Synthesis of the chromogenic substrate $p$-nitrophenyl 6-phospho- $\beta$-D-glucoside (pNP $\beta$ G6P) is accomplished enzymatically with BglK as described by Thompson ${ }^{1}$ with minor modifications. 2-[2 $\mathrm{H}]-\mathrm{D}-\mathrm{Glucopyranose}$ was purchased from Cambridge Isotope Laboratories, Inc. 3-[ $\left[{ }^{2} \mathrm{H}\right]-\mathrm{D}-\mathrm{Glucopyranose}$ was synthesized from 1,2:5,6-di-Oisopropylidene- $\alpha$-D-ribo-3-hexulofuranulose hydrate, which was purchased from CMS Chemicals Ltd., based on published procedures ${ }^{2,3}$. The deuterated $p$-nitrophenyl $\beta$-Dglucosides, $p$-nitrophenyl 3- $\left[{ }^{2} \mathrm{H}\right]-6$-phospho- $\beta$-D-glucoside $\left(3-\left[{ }^{2} \mathrm{H}\right]-\mathrm{pNP} \beta \mathrm{G} 6 \mathrm{P}\right)$ and $p$ nitrophenyl 2-[ $\left.{ }^{2} \mathrm{H}\right]-6$-phospho- $\beta$-D-glucoside $\left(2-\left[{ }^{2} \mathrm{H}\right]-\mathrm{pNP} \beta \mathrm{G} 6 \mathrm{P}\right)$, were synthesized via the Koenigs-Knorr reaction, ${ }^{4}$ following which phosphorylation at the C6 position was carried out enzymatically using BglK. All other chemicals were obtained from SigmaAldrich unless otherwise stated.

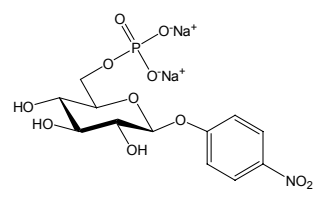

p-Nitrophenyl 6-phospho- $\beta$-D-glucoside (pNP $\beta$ G6P)

${ }^{1} \mathbf{H}$ NMR (500 MHz, D $\left.2 \mathrm{O}\right) \delta$ 8.16-8.12 (2 H, m, H3', H5'), 7.15-7.12 (2 H, m, H2', H6'), 5.17-5.12 (1 H, m, H1), 3.98-3.93 (1 H, m, H6 $\left.6_{\mathrm{a}}\right), 3.89-3.85$ (1 H, m, H6 $)$, 3.64-3.58 (2 H, m, H4, H5), 3.55-3.50 (2 H, m, H2, H3); ${ }^{13} \mathbf{C}$ NMR (100 MHz, D $\left.2 \mathrm{O}\right) \delta 161.64$ (C), $142.30(\mathrm{C}), 126.00(2 \mathrm{CH}), 116.34(2 \mathrm{CH}), 99.54(\mathrm{C} 1), 75.77$ (d, J $\left.\mathrm{J}_{\mathrm{C}, \mathrm{P}} 7.0 \mathrm{~Hz}, \mathrm{C} 5\right), 74.63$ (C3), 72.87 (C2), 68.43 (C4), 62.14 (d, J 6, P $4.5 \mathrm{~Hz}, \mathrm{C} 6) ;{ }^{31}$ P NMR (162 MHz, D $\left.2 \mathrm{O}\right) \delta$
\end{abstract}


$5.21\left(\mathrm{t}, \mathrm{J}_{\mathrm{H} 6, \mathrm{P}} 5.9 \mathrm{~Hz}\right.$ ); High-resolution ESI-MS m/z calc. for $\mathrm{C}_{12} \mathrm{H}_{15} \mathrm{NO}_{11} \mathrm{P}^{-} 380.0383$, found: 380.0391; Anal. calc. for $\mathrm{C}_{12} \mathrm{H}_{14} \mathrm{NNa}_{2} \mathrm{O}_{11} \mathrm{P} \cdot 3 \mathrm{H}_{2} \mathrm{O}: \mathrm{C}, 30.07 ; \mathrm{H}, 4.21 ; \mathrm{N}, 2.92 ; \mathrm{Na}$, 9.59; O, 46.74; P, 6.46, found: C, 30.26; H, 4.13; N, 2.96 .

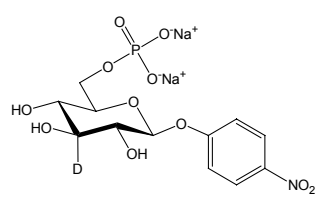

p-Nitrophenyl 3-[ $\left.{ }^{2} \mathrm{H}\right]-6-$ phospho- $\beta$-D-glucoside (3-[ $\left.{ }^{2} \mathrm{H}\right]-$-pNPßG6P)

${ }^{1} \mathbf{H}$ NMR $\left(400 \mathrm{MHz}, \mathrm{D}_{2} \mathrm{O}\right) \delta 8.10\left(2 \mathrm{H}, \mathrm{d}, \mathrm{J}_{2}, 3^{\prime}=\mathrm{J}_{5^{\prime}, 6^{\prime}} 9.3 \mathrm{~Hz}, \mathrm{H} 3\right.$ ', H5'), $7.10(2 \mathrm{H}, \mathrm{d}$, $\left.\mathrm{J}_{2^{\prime}, 3^{\prime}}=\mathrm{J}_{5^{\prime}, 6^{\prime}} 9.3 \mathrm{~Hz}, \mathrm{H} 2^{\prime}, \mathrm{H} 6^{\prime}\right), 5.11\left(1 \mathrm{H}, \mathrm{d}, \mathrm{J}_{1,2} 7.9 \mathrm{~Hz}, \mathrm{H1}\right), 3.94-3.89$ (1 H, m, H6 ${ }^{2}$, 3.85-3.80 (1 H, m, H6 $)$ ), 3.59-3.54 (2 H, m, H4, H5), $3.49\left(1 \mathrm{H}, \mathrm{d}, \mathrm{J}_{1,2} 7.9 \mathrm{~Hz}, \mathrm{H} 2\right) ;{ }^{13} \mathbf{C}$ NMR $\left(125 \mathrm{MHz}, \mathrm{D}_{2} \mathrm{O}\right) \delta 161.98(\mathrm{C}), 142.85(\mathrm{C}), 126.39(2 \mathrm{CH}), 116.75(2 \mathrm{CH}), 99.85$ (C1), 76.16 (d, J $\left.\mathrm{J}_{\mathrm{C}, \mathrm{P}} 6.9 \mathrm{~Hz}, \mathrm{C} 5\right), 74.56$ (t, J $\left.\mathrm{J}_{\mathrm{C} 3, \mathrm{D}} 21.0 \mathrm{~Hz}, \mathrm{C} 3\right), 73.17$ (C2), 68.70 (C4), $62.44\left(\mathrm{~d}, \mathrm{~J}_{\mathrm{C} 6, \mathrm{P}} 4.3 \mathrm{~Hz}, \mathrm{C} 6\right) ;{ }^{31}$ P NMR $\left(162 \mathrm{MHz}, \mathrm{D}_{2} \mathrm{O}\right) \delta 5.04$ (t, $\left.\mathrm{J}_{\mathrm{H} 6, \mathrm{P}} 6.1 \mathrm{~Hz}\right)$; Highresolution ESI-MS m/z calc. for $\mathrm{C}_{12} \mathrm{H}_{14} \mathrm{DNO}_{11} \mathrm{P}^{-} 381.0446$, found: 381.0451 ; Anal. calc. for $\mathrm{C}_{12} \mathrm{H}_{13} \mathrm{DNNa}_{2} \mathrm{O}_{11} \mathrm{P} \cdot 3 \mathrm{H}_{2} \mathrm{O}: \mathrm{C}, 30.01 ; \mathrm{H}, 4.20 ; \mathrm{N}, 2.92 ; \mathrm{Na}, 9.57 ; \mathrm{O}, 46.64 ; \mathrm{P}$, 6.45, found: $\mathrm{C}, 29.24 ; \mathrm{H}, 4.12 ; \mathrm{N}, 2.64$.

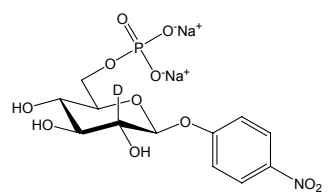

p-Nitrophenyl 2-[ $\left.{ }^{2} \mathrm{H}\right]-6$-phospho- $\beta$-D-glucoside $\left(2-{ }^{2} \mathrm{H}\right]-$-pNP $\left.\beta G 6 \mathrm{P}\right)$

${ }^{1} \mathbf{H}$ NMR $\left(300 \mathrm{MHz}, \mathrm{D}_{2} \mathrm{O}\right) \delta 8.12\left(2 \mathrm{H}, \mathrm{d}, \mathrm{J}_{2^{\prime}, 3^{\prime}}=\mathrm{J}_{5^{\prime}, 6^{\prime}} 9.3 \mathrm{~Hz}, \mathrm{H} 3^{\prime}, \mathrm{H} 5^{\prime}\right), 7.09(2 \mathrm{H}, \mathrm{d}$, $\left.\mathrm{J}_{2^{\prime}, 3^{\prime}}=\mathrm{J}_{5^{\prime}, 6^{\prime}} 9.3 \mathrm{~Hz}, \mathrm{H} 2^{\prime}, \mathrm{H} 6^{\prime}\right), 5.10(1 \mathrm{H}, \mathrm{s}, \mathrm{H} 1), 3.93-3.81$ (2 H, m, H6 $\left.{ }_{\mathrm{a}}, \mathrm{H6}_{\mathrm{b}}\right), 3.60-3.48$ $(3 \mathrm{H}, \mathrm{m}, \mathrm{H} 3, \mathrm{H} 4, \mathrm{H} 5) ;{ }^{13} \mathbf{C}$ NMR $\left(100 \mathrm{MHz}, \mathrm{D}_{2} \mathrm{O}\right) \delta 161.67$ (C), 142.54 (C), 126.07 $(2 \mathrm{CH}), 116.43(2 \mathrm{CH}), 99.49(\mathrm{C} 1), 75.84\left(\mathrm{~d}, \mathrm{~J}_{\mathrm{C} 5, \mathrm{P}} 6.9 \mathrm{~Hz}, \mathrm{C} 5\right), 74.65(\mathrm{C} 3), 72.50\left(\mathrm{t}, \mathrm{J}_{\mathrm{C} 2, \mathrm{D}}\right.$ $23.3 \mathrm{~Hz}, \mathrm{C} 2), 68.45(\mathrm{C} 4), 62.12\left(\mathrm{~d}, \mathrm{~J}_{\mathrm{C} 6, \mathrm{P}} 4.4 \mathrm{~Hz}, \mathrm{C} 6\right) ;{ }^{31}$ P NMR $\left(162 \mathrm{MHz}, \mathrm{D}_{2} \mathrm{O}\right) \delta 5.07$ (t, $\mathrm{J}_{\mathrm{H} 6, \mathrm{P}} 6.0 \mathrm{~Hz}$ ); High-resolution ESI-MS m/z calc. for $\mathrm{C}_{12} \mathrm{H}_{14} \mathrm{DNO}_{11} \mathrm{P}^{-} 381.0446$; found: 381.0441; Anal. calc. for $\mathrm{C}_{12} \mathrm{H}_{13} \mathrm{DNNa}_{2} \mathrm{O}_{11} \mathrm{P} \cdot 3 \mathrm{H}_{2} \mathrm{O}: \mathrm{C}, 30.01 ; \mathrm{H}, 4.20 ; \mathrm{N}, 2.92$; $\mathrm{Na}, 9.57$; O, 46.64; P, 6.45, found: C, $30.22 ; \mathrm{H}, 4.00 ; \mathrm{N}, 3.19$.

Enzyme Kinetics. All experiments were carried out at $50{ }^{\circ} \mathrm{C}$ in $50 \mathrm{mM}$ HEPES buffer, $\mathrm{pH} 7.5,1 \mathrm{mM} \mathrm{MnCl}_{2}, 0.001 \mathrm{mM} \mathrm{NAD}^{+}, 10 \mathrm{mM}$ mercaptoethanol, and $0.1 \%$ (w/v) BSA. Activity of BglT was measured with pNP $\beta$ G6P by monitoring the release of the $p$ nitrophenolate anion at $400 \mathrm{~nm}$ in $1 \mathrm{~cm}$ path length matched quartz cuvettes with a Varian Cary 300 UV-Vis spectrometer equipped with a circulating water bath, or a Varian Cary 4000 UV-Vis spectrometer with a Cary Temperature Controller attached. The enzyme (final concentration of $2.87 \mu \mathrm{g} / \mathrm{mL}$ ) is preincubated with the above solution at $50{ }^{\circ} \mathrm{C}$, and the initial linear rate of increase in absorbance at $400 \mathrm{~nm}$ is measured upon addition of pNP $\beta$ G6P to a final assay volume of $200 \mu \mathrm{L}$. The difference in extinction coefficients $\Delta \varepsilon$ between pNP $\beta$ G6P and the $p$-nitrophenolate anion at $\mathrm{pH} 7.5,50{ }^{\circ} \mathrm{C}$ was determined to be $13,791 \mathrm{M}^{-1} \mathrm{~cm}^{-1}$, and the catalytic parameters were determined based on a direct fit of the data to the Michaelis-Menten equation. 
Methanolysis. All buffers and chemicals were lyophilized twice from $99.9 \% \mathrm{D}_{2} \mathrm{O}$. BglT was exchanged into deuterated buffer solutions via repeated (three times) dilution and concentration using a centrifugal filter unit (Millipore) with a nominal molecular weight limit (NMWL) of $10 \mathrm{kDa}$. The enzymatic reaction was performed under the following conditions: $50 \mathrm{mM}$ HEPES $\mathrm{pH} 7.5,1 \mathrm{mM} \mathrm{MnCl}_{2}, 0.001 \mathrm{mM} \mathrm{NAD}^{+}, 0.4$ $\mathrm{mg} / \mathrm{mL} \mathrm{BglT}$, and $5 \mathrm{M} \mathrm{CD}_{3} \mathrm{OD}$. PNP $\beta \mathrm{G} 6 \mathrm{P}(20 \mathrm{mg})$ was incubated at $50{ }^{\circ} \mathrm{C}$ in $5 \mathrm{~mL}$ of the above solution and the reaction was monitored by TLC (2:1:1 1-butanol: $\mathrm{H}_{2} \mathrm{O}$ :acetic acid). Upon completion, the enzyme was removed using a $10 \mathrm{kDa}$ NMWL centrifugal filter unit. $100 \mathrm{mg}$ of Chelex 100 resin (BioRad) was added to the filtrate and stirred at room temperature for 30 minutes to remove metal ions. The suspension was then filtered and the solution was lyophilized, then redissolved in $\mathrm{D}_{2} \mathrm{O}$ for ${ }^{1} \mathrm{H}$ NMR analysis.

Solvent Deuterium Isotope Exchange. All buffers and chemicals were lyophilized twice from $99.9 \% \mathrm{D}_{2} \mathrm{O}$. BglT was exchanged into deuterated buffer solutions via repeated (three times) dilution and concentration using a centrifugal filter unit (Millipore) with a nominal molecular weight limit (NMWL) of $10 \mathrm{kDa}$. The enzymatic reactions were performed under the following conditions: $50 \mathrm{mM}$ HEPES pH 7.5, $1 \mathrm{mM} \mathrm{MnCl}_{2}$, $0.001 \mathrm{mM} \mathrm{NAD}{ }^{+}, 0.4 \mathrm{mg} / \mathrm{mL}$ BglT. PNP $\beta$ G6P $(20 \mathrm{mg})$ was incubated at $50^{\circ} \mathrm{C}$ in $5 \mathrm{~mL}$ of the above solution and the reaction was monitored by TLC. Upon completion, the enzyme was removed using a $10 \mathrm{kDa}$ NMWL centrifugal filter unit. $100 \mathrm{mg}$ of Chelex 100 resin was added to the filtrate and stirred at room temperature for 30 minutes. The Chelex resin was removed via filtration, and the solution was lyophilized then redissolved in $\mathrm{D}_{2} \mathrm{O}$ for ${ }^{1} \mathrm{H}$ NMR analysis. In an identical control experiment, the above solution was incubated at $50{ }^{\circ} \mathrm{C}$ without enzyme. Two other controls involved ${ }^{1} \mathrm{H}$ NMR analysis of reaction mixtures in which the product glucose 6-phosphate (G6P) had been incubated with the buffer and cofactors in the presence and absence of BglT. The same deuterium exchange experiments were performed with 1,5-anhydroglucitol 6-phosphate.

Kinetic Isotope Effects. All experiments were carried out at $50{ }^{\circ} \mathrm{C}$ in $1 \mathrm{~cm}$ path length matched quartz cuvettes under the following conditions: $50 \mathrm{mM} \mathrm{HEPES,} 1 \mathrm{mM} \mathrm{MnCl}_{2}$, $0.001 \mathrm{mM} \mathrm{NAD}^{+}, 10 \mathrm{mM}$ mercaptoethanol, and $0.1 \%$ (w/v) BSA at $\mathrm{pH} 7.5,50{ }^{\circ} \mathrm{C}$. For $k_{\mathrm{H}} / k_{\mathrm{D}}$ measurements, BglT (final concentration of $2.87 \mu \mathrm{g} / \mathrm{mL}$ ) was preincubated with the above solution for 5 minutes, and substrate was added to the reaction mixture to give a final volume of $1 \mathrm{~mL}$. Final substrate concentration was chosen to be $615 \mu \mathrm{M}$ (over 10 times $K_{\mathrm{M}}$ ) to measure catalytic rates. Measurements for substrates, PNP $\left.\beta \mathrm{G} 6 \mathrm{P}, 3-{ }^{2} \mathrm{H}\right]-$ PNP $\beta$ G6P and 2- $\left[{ }^{2} \mathrm{H}\right]-\mathrm{PNP} \beta \mathrm{G} 6 \mathrm{P}$, were repeated 10 times each, and KIEs were calculated from the data.

For $\left(k_{\text {cat }} / K_{\mathrm{M}}\right)_{\mathrm{H}} /\left(k_{\text {cat }} / K_{\mathrm{M}}\right)_{\mathrm{D}}$ measurements, BglT (final concentration $5.73 \mu \mathrm{g} / \mathrm{mL}$ ) was preincubated with the buffer and cofactors at $50{ }^{\circ} \mathrm{C}$ for 5 minutes, and PNP $\beta$ G6P, 3$\left[{ }^{2} \mathrm{H}\right]-\mathrm{PNP} \beta \mathrm{G} 6 \mathrm{P}$, or $2-\left[{ }^{2} \mathrm{H}\right]-\mathrm{PNP} \beta \mathrm{G} 6 \mathrm{P}$, (final concentration of $6.15 \mu \mathrm{M}$, at a concentration that was equal to $0.15 K_{\mathrm{M}}$ was used individually to initiate the enzymatic reaction. The absorbance at $400 \mathrm{~nm}$ was monitored until the substrate was depleted. The data set was fitted to a first order curve, and the $k_{\text {cat }} / K_{\mathrm{M}}$ values were obtained by dividing this value by the enzyme concentration. Each measurement was repeated 8 times, and the $\left(k_{\text {cat }} / K_{\mathrm{M}}\right)_{\mathrm{H}} /\left(k_{\mathrm{cat}} / K_{\mathrm{M}}\right)_{\mathrm{D}}$ value was calculated. 


\section{Expression and purification.}

T. maritima genomic DNA was obtained from ATCC (ATCC 43589). The Escherichia coli strains used in this study were XL2blue for DNA isolation and B834 (DE3)

(Novagen) for protein expression. The plasmids were pCR $®$-Blunt (Invitrogen) and Pet16b vector (Novagen). All strains harboring plasmids were grown in Luria broth media supplemented with either $30 \mu \mathrm{g} \mathrm{ml}^{-1}$ Kanamycin for $\mathrm{pCR} \AA-B l u n t$ or $100 \mu \mathrm{g} / \mathrm{ml}^{-1}$ Ampicillin for Pet16b.

The TM1281 (bglt) gene was amplified from genomic DNA using the following primers: forward primer including a NdeI restriction site 5'-

CATATGAGAATTGCGGTGATAGGTGGG GGAAGCAGC-3' and reverse primer including a BamHI site (underlined) 5'-GGATCCCTATCACCCC

AGTTTCACGTATTCTCTGTTCGC-3'. A blunt $1.25 \mathrm{~kb}$ fragment was amplified using the Vent polymerase (BioLabs) and inserted in $\mathrm{pCR} \AA$-Blunt vector (Invitrogen). Positive transformants were screened by restriction site analysis. A NdeI-BamHI fragment was then isolated and inserted into high expression vectors to produce Pet16b-bglt (Nterminal His-tag). These plasmids were used to transform E. coli B834 (DE3) cells. The sequence of the gene was confirmed by automated DNA sequencing.

For expression of the bglt gene cells were grown in Luria broth media supplemented with $100 \mu \mathrm{g} \mathrm{ml}^{-1}$ Ampicillin at $37^{\circ} \mathrm{C}$ to an $\mathrm{OD}_{595 \mathrm{~nm}}$ of approximately 0.6 before induction with $0.1 \mathrm{mM}$ IPTG. Overnight cultures were harvested by centrifugation (10 min at $5000 \mathrm{rpm})$ and the pellet from $1 \mathrm{~L}$ of culture resuspended in $30 \mathrm{ml} 50 \mathrm{mM}$ Tris $\mathrm{HCl} \mathrm{pH} 8.0,500 \mathrm{mM}$ $\mathrm{NaCl}$ buffer with Bugbuster (Novagen). Benzonase (Novagen, $30 \mu \mathrm{l}$ ) was added to digest DNA. After 30 minutes incubation and occasional shaking, the cells were centrifuged 30 minutes at $4{ }^{\circ} \mathrm{C}$ and $18000 \mathrm{rpm}$ in order to removed cell debris and intact cells. The supernatant was collected and incubated for $15 \mathrm{~min}$ at $70^{\circ} \mathrm{C}$ to denature the nonthermally stable $E$. coli proteins. After centrifugation at $18000 \mathrm{rpm}$ for $30 \mathrm{~min}$, the clarified supernatant was recovered and loaded on $3 \mathrm{ml}$ chelating column (Amersham) saturated with $\mathrm{Ni}^{2+}$ equilibrated with $50 \mathrm{mM}$ Tris $\mathrm{HCl} \mathrm{pH} 8.0,500 \mathrm{mM} \mathrm{NaCl}$ and $5 \mathrm{mM}$ imidazole. The column was washed with $120 \mathrm{mM}$ imidazole before elution of the protein with $500 \mathrm{mM}$ imidazole. Fractions containing His-BglT were pooled and concentrated before further purification by gel filtration (Superdex S200 16/60, Pharmacia-Biotech) in $20 \mathrm{mM}$ Hepes $\mathrm{pH} 7.0$ and $100 \mathrm{mM} \mathrm{NaCl}$. Protein purity was assessed by SDS-PAGE (10 $\%$ gel) and the concentration determined using the calculated extinction coefficient of $33600 \mathrm{M}^{-1} \mathrm{~cm}^{-1}$ at $280 \mathrm{nM}$.

\section{Structure Solution}

Details of the 3-D structure solution for BglT will be published elsewhere (Varrot et al., in preparation). The 3-D coordinates are available from the Protein Data Bank with accession code 1 up6.

References:

(1) Thompson, J.; Lichtenthaler, F. W.; Peters, S.; Pikis, A. J. Biol. Chem. 2002, 277, 34310-34321.

(2) Sowa, W.; Thomas, G. H. S. Can. J. Chem. 1966, 44, 836-838. 
(3) Koch, H. J.; Perlin, A. S. Carbohyd. Res. 1970, 15, 403-410.

(4) Conchie, J.; Levvy, G. A. Methods in Carbohydrate Chemistry II 1963, 335-337. 